нием определенных Стандартных операчионных прочедур (СОП), введенных правительством, чтобы избежать заражения вирусом COVID-19 и практиковать сочиальное дистанцирование на рабочем месте. Помимо новой нормы, есть некоторые последствия для полупроводниковых компаний, которые могут оказать негативное влияние на будущее компаний. Принимаются некоторые радикальные меры, чтобы адаптироваться к новому нормальному режиму, а также сохранить производство в обычном режиме. Главный мотив анализа текущей ситуации - избежать полного спада производства полупроводниковых компаний, который может повлиять на мировую экономику.

Ключевые слова: пандемия COVID-19, новая норма, полупроводниковые компании, мировая экономика.

ГРНТИ 06.51.02

УДК 338

https://doi.org/10.51579/1563-2415.2021-4.20

\title{
STOCK MARKET RESPONSES TO COVID-19 CASES: UNLOCKING MA- LAYSIA'S FUTURE
}

\author{
Shairil Izwan T. ${ }^{1 *}$, Neilson $T^{1}$, Edwin $F_{.}^{2}$, Boon Yik W. $^{3}$, Gulzhaina K. Kassymova ${ }^{4}$ \\ ${ }^{1}$ Department of Social Science and Management, Faculty of Humanities, Management \\ and Science, Universiti Putra Malaysia, Campus Bintulu, Malaysia. \\ ${ }^{2}$ Cluster of Business and Management, Open University Malaysia, Malaysia \\ ${ }^{3}$ Faculty of Business, Economics and Accountancy, Universiti Malaysia Sabah, Ma- \\ laysia \\ ${ }^{4}$ Institute Metallurgy and Ore Beneficiation, Satbayev University; Abai Kazakh Na- \\ tional Pedagogical University, Almaty, Kazakhstan \\ e-mail: shairil@upm.edu.my
}

\begin{abstract}
The COVID-19 pandemic has posed a major health and economic crisis on a global scale. The waves of this crisis hit Malaysia since early March 2020. This unpredicted crisis is among the obstacles faced by Malaysia towards the country's mission of development in 2020. However, the country is still in the line of planning and introduced its mission and vision of shared prosperity in 2030. In contrast, during this crisis, the impact has especially been hard on vulnerable groups. The stock market of Malaysia was also affected. The government introduced a stimulus package to attempt to recover the economy. This study focuses on KLCI Index on the impact of COVID-19 cases reported on day trading and macroeconomic variables during the year 2020. We employ the Bound Test to identify the co-integration and perform the ARDL. The results show that the cases reported have a significant impact on macroeconomic variables and the stock market in both the short-and long run. In conclusion, we found that the effective management of a health crisis is one of the best solutions to reduce the negative impact on economic performance and recover from any crisis.
\end{abstract}

Keywords: Covid-19, Stata, Growth, Stock Market. 
Basic Provisions. This article studies the daily cumulative COVID-19 cases with the effect on macroeconomic variable exchange rates in Malaysia. As a research result, exchange rates to US Dollar are affected in both the short-run and the long-run.

Introduction. The first COVID-19 cases in Malaysia were reported on 25 January, 2020, by three tourists from China. Two months after the first cases reported in the country, the government enforced a total lockdown on 18 March, 2020. The implication from this policy affected the economy, with an average of RM 2.4 billion in losses on a daily basis. However, health and economic crises or the lockdown crisis is one of the alternatives for the overall well-being of Malaysians. However, to respond to the total lockdown, Malaysia introduced a stimulus package to help boost the economy. Previous research examined the impact of COVID-19 on the economy. Notably, Baek, Mohanty and Glambosky (2020) mention that the recent coronavirus (COVID-19) outbreak has resulted in unprecedented volatility in the U.S. financial markets [1]. The movement control order restrictions in Malaysia in 2020 has left a large impact on the stock market. This study examines the effect of reported cases of COVID19 on the stock market and the currency exchange, once Bursa Malaysia opened for trading.

Literature Review. Malaysia is in the midst of economic recovery after COVID-19 was first announced as a global pandemic. Since COVID-19 had emerged, the education system changed from traditional to technology-based approaches [2;3;4]. Investors and the market were affected since the early movement restrictions. According to Sha and Sharma (2020), COVID-19 has affected economic and financial systems [5]. Wang et al. (2013) investigated health and economic issues during a crisis [6]. The outbreak of a contagious disease does not only affect the health and lives of people, but also causes economic growth to stagnate. In terms of stock market performance, Onali (2020) identified a significant increase in volatility for the U.S. stock market, in response to reports of COVID-19 cases and deaths in multiple countries [7]. However, the study by Narayan (2020) for the Japanese Yen has become more resistant to COVID-19 effects, compared to the pre-COVID-19 era [10].

Since the policy of Malaysia's open market system to attract investors, the stock market is one of the main sources of income for businesses. The market interacts with implication of news and economic problems. The study by Carpentier and Suret (2015) indicates that the market reacts negatively and enduringly to an announcement of a major nation-wide crisis. It is important to investigate the reaction of the stock market on environmental and nonenvironmental problematic events [8]. Meanwhile, Narayan, Devpura and Wang (2020) investigate the value rate of the Yen-US Dollar and its effected financial and economic systems during COVID-19 [9]. The authors found that during the pandemic, the relationship of the exchange rate of the Yen Japan grew stronger. In the same vein, a Markov Switching AR Model regime changed from lower to higher volatility and was affected by sensitivity to COVID-19 news [1]. The study examined the US stock market and the author mentioned that COVID-19 news has a greater influence than economic indicators.

Methodology. We applied the Malaysia stock market and macroeconomic variables responses to the daily cumulative reporting of COVID-19 cases in 2020. Meanwhile, the response of the stock market index of Bursa Malaysia to the cumulative daily COVID-19 cases was investigate. These data on the stock market were taken from Marketwatch.com and Bank Negara Malaysia in terms of macroeconomic variables. The data on the Coronavirus disease (COVID-19) pandemic daily cases information were derived from records by the World Health Organization (WHO). To fully capture this analysis, we employed the Autoregressive Distributed Lag (ARDL) method.

Our method takes the log-linear value for the independent and dependent variables, and estimates the final value using the following equation: 


$$
\lg (\text { cases })_{t}=\beta_{0}+B_{1} k l s e_{t-i}+\beta_{2} x u s d_{t-i}+\beta_{3} o p r_{t-i}+\mu_{t}
$$

where $t$ stands for time period of $t-i$ for cases reported at the time. This demonstrates the cases' interaction with the days after the cases were reported. $B_{1}$ kls $_{t-1}$ is the natural logarithm of the FTSE Bursa Malaysia KLCI also known as the FBM KLCI once the market was open, $\beta_{2} x u s d_{t-1}$ is the rate of exchange in Ringgit Malaysia to US Dollar, and $\beta_{3} o p r_{t-1}$ is the rate of overnight policy rate.

To establish an econometric model, the following requirements and procedures were needed to specify the model. In regression and time series analysis, if its mean, variance and autocovariance remain unchanged through the time period, it is considered to be weakly stationary. To detect the stationary value of the variable, we employ Augmented Dickey-Fuller (ADF). Non-stationary series will lead a spurious regression, with $\mathrm{R}^{2}$ and t-statistics that appear to be significant, but the results are without any meaning economically [11].

The ARDL model can overcome the problems of economic interpretation of analysis of the causality between time series data through the econometric model. If we choose the right model, the long-run and short-run relationship for some variables may not be stationary. Some may integrate at $1^{\text {st }}$ difference. The ARDL model can play an important role here. Pesaran et al. (2001) mentioned that the ARDL model must be consistent with economic theory, and no variable is I(2) [12]. The dependent variable should at least have a weakly exogenous relationship with the parameters. The ARDL equation model is specified as follows:

$$
\lg (\text { cases })_{t}=\beta_{0}+\sum_{i=1}^{\rho} \delta_{1 i} \text { klse }_{t-1}+\sum_{i=0}^{q} \delta_{2 i} x u s d_{t-1}+\sum_{i=0}^{r} \delta_{1 i} \text { opr }_{t-i}+\varepsilon_{t}
$$

where $\delta$ represents the difference operator. If there is cointegration, the error correction model (ECM) for the estimation of the short-run is specified as follows:

$$
\begin{gathered}
\Delta l g(\text { cases })_{t}=\beta_{0}+\sum_{i=1}^{\rho} \delta_{1 i} \Delta k l s e_{t-1}+\sum_{i=0}^{q} \delta_{2 i} \Delta x u s d_{t-1}+\sum_{i=0}^{r} \delta_{1 i} \Delta o p r_{t-i} \\
+e c t_{t-1}+\varepsilon_{t}
\end{gathered}
$$

The 'ect' represents the residuals from the regression of the long-run equation for the error correction term. To estimate the long-run model, which is the error correction model, we applied the Bound Test. Bertsatos et al. (2021) mentioned that the Bound Testing procedure is a series of tests that imply the existence of co-integration, once their null hypotheses are jointly rejected [11]. If the F-statistic is greater than the critical value, we can conclude that there is cointegration, and we perform ECM.

Results and Discussion. We present the results obtained from the analysis discussed before. The data for the Malaysian stock market index KLCI is based on the opening trading day, with an interaction with the total COVID-19 cases. For the gap of non-trading days with the reported cases of COVID-19, we fix the date indicator with the uniform time trend. The integration of a time series is important for the analysis, and we test the null hypothesis if a unit root against the alternative is stationary. 
Table 1. Augmented Dickey-Fuller

\begin{tabular}{|l|c|c|c|c|}
\hline & Test statistic & $1 \%$ & $5 \%$ & $10 \%$ \\
\hline Cases & -4.215 & -2.343 & -1.652 & -1.285 \\
\hline opr & -11.924 & -3.468 & -2.882 & -2.572 \\
\hline usdxmyr & -8.696 & -3.468 & -2.882 & -2.572 \\
\hline KLSE & -7.552 & -3.468 & -2.882 & -2.572 \\
\hline
\end{tabular}

Table 2. Results of the Bounds Test of cointegration

\begin{tabular}{|c|c|c|c|c|}
\hline \multicolumn{2}{|l|}{ Estimated Model } & \multicolumn{3}{|c|}{ lg_cases(Index) } \\
\hline \multicolumn{2}{|c|}{ Optimal lag length AIC } & \multicolumn{3}{|c|}{$-27.8509(2)$} \\
\hline \multicolumn{2}{|c|}{ F-statistic (Bound Test) } & \multicolumn{3}{|c|}{$5.690 *$} \\
\hline Critical Values & $1 \%$ & $2 . .5 \%$ & $5 \%$ & $10 \%$ \\
\hline Lower Bounds I $(0)$ & 2.72 & 3.23 & 3.69 & 4.29 \\
\hline Upper Bounds I(1) & 3.77 & 4.35 & 4.89 & 5.61 \\
\hline $\mathrm{R} 2$ & \multicolumn{4}{|c|}{0.5122} \\
\hline Adj R2 & \multicolumn{4}{|c|}{0.4893} \\
\hline
\end{tabular}

ly. The critical values were determined from Pesaran et al. (2001).

Therefore, in this study, we have used the ADF unit root test presented in table 1 . The results show that the variable of the study is stationary at different orders. The next analysis is to check the appropriate lag length before applying the ARDL Bound Test. Meanwhile, table 2 , the ARDL $(3,0,0,0)$ model was selected based on Akaike Information Criterion. According to Chandio, Jiang and Rehman (2019), the choice of lag length should be exercised with caution, as an inappropriate lag length can lead to biased results and cannot be accepted for policy analysis [13]. Table 2 shows the Bound Testing for interactions among the variables considered. If the test rejects the null hypothesis, this shows that the model has a long-run relationship, and error correction might be estimated. The F-statistics for testing are compared with the critical values, and the results are greater than the critical value for the upper bound. We thus conclude that there is cointegration.

Table 3. ARDL estimation

\begin{tabular}{|l|c|c|c|c|c|c|}
\hline Cases & Coef. & Std. Err & $\mathrm{T}$ & $\mathrm{p}>\mathrm{t}$ & \multicolumn{2}{c|}{$95 \%$ conf. Interval } \\
\hline L1 & -0.3475 & 0.35469 & -0.98 & 0.331 & -1.0547 & 0.3597 \\
\hline L2 & 2.0451 & 0.5004 & 4.09 & $0.000^{*}$ & 1.0473 & 3.0429 \\
\hline L3 & -0.7117 & 0.2376 & -3.00 & $0.004^{*}$ & -1.1854 & -0.2379 \\
\hline KLSE & -1.5325 & 0.4461 & -3.44 & $0.001^{*}$ & -2.4219 & -0.6431 \\
\hline usdxmyr & -2.1149 & 1.0312 & -2.05 & $0.044^{*}$ & -4.1711 & -0.0586 \\
\hline opr & -0.0879 & 0.1933 & -0.46 & 0.650 & -0.4735 & 0.2975 \\
\hline -Cons & 6.035 & 1.9693 & 3.2 & $0.002^{*}$ & 2.3769 & 10.2301 \\
\hline \multicolumn{2}{|c|}{ Prob>F } & 0.000 & & Root MSE & \multicolumn{2}{c|}{0.0539} \\
\hline \multicolumn{2}{|c|}{ R-Squared } & 0.9977 & & AIC & $-28.5866(\operatorname{Lag} 3)$ \\
\hline \multicolumn{2}{|c|}{ Adj R-Squared } & 0.9975 & & SBIC & $-26.2758(\operatorname{Lag} 3)$ \\
\hline
\end{tabular}

*Significant at $1 \%$ 
Table 4. Autoregressive Distributed Lag (ARDL) long-run results with the error correction term.

\begin{tabular}{|l|c|c|c|c|}
\hline Variable & Coefficient & Std Err. & t-statistic & Prob. \\
\hline KLSE & -4.182703 & 2.322151 & -1.80 & $0.073^{*}$ \\
\hline usdxmyr & 1.543286 & 3.865593 & 0.40 & 0.690 \\
\hline opr & 0.0346342 & 0.6369088 & 0.05 & 0.957 \\
\hline ECT $_{\mathrm{t}-1}$ & -0.4277224 & .0898343 & -4.76 & $0.000^{*}$ \\
\hline $\mathrm{R}^{2}$ & 0.5122 & Adj. $\mathrm{R}^{2}$ & 0.4893 & \\
\hline F-statistic & & DW & 2.063553 & \\
\hline
\end{tabular}

*Significant at $1 \%$

The table 3 shows that the independent variable for the open trading index stock market KLCI is significant towards the total cases reported. This also applies to the foreign exchange of Ringgit Malaysia to US Dollar. In terms of lag, the percentage points change in the second lag of cases and this is associated with a positive (2.0451) percentage point increase in the cases on average. The $1 \%$ significance and the -0.7116 decline at the $1 \%$ significant can be witnessed at lag 3. We find that the coefficient for the stock market index and exchange rate (USD) are negative and statistically significant at the $1 \%$ level. This shows that an increase in total COVID-19 cases leads to a lower index of stock market, and this will devalue the Malaysian Ringgit. We include additional variables in the specification model; the overnight policies rate is insignificant at this level and the value is also negative. Hence, our results show that the OPR are controlled by Bank Negara Malaysia, and do not affect the total cases of COVID-19. The Monetary Policy Committee (MPC) discusses the OPR in the schedule by BNM. The long-run coefficient of the open trading index is negative and statistically significant in the long-run. The value of ECT is $-4.27 \%$, and is statistically significant at $1 \%$. The results in Table 4 show the cumulative COVID-19 daily cases, and this converges on its long-run equilibrium with the speed adjustment via the open trading of KLSE.

Table 5. Results of diagnostics test

\begin{tabular}{|l|c|c|}
\hline Test & chi2 & Prob. \\
\hline $\begin{array}{l}\text { Breusch-Godfrey LM test } \\
\text { for autocorrelation }\end{array}$ & 17.601 & 0.0002 \\
\hline $\begin{array}{l}\text { White Heteroskedasticity } \\
\text { test }\end{array}$ & 215.77 & 0.0000 \\
\hline
\end{tabular}

If model defects such as residual autocorrelation are detected during the checking stage, this indicates that the model is a poor representation of the dependent variable. The results in Table 5 test the underlying ARDL equation. The model fits very well and is significant at the $1 \%$ level. Each diagnostics test passes against a serial correlation as mentioned by Breusch-Godfrey and White Heteroscedasticity.

Conclusion. This study examines the relationship between total daily cumulative COVID-19 cases with the effect on the KLCI Index and macroeconomic variable exchange rate and overnight policy rate by using the ARDL approach proposed by Pesaran et al. (2001). The empirical study concludes that open trading for KLCI index and Ringgit Malaysia exchange rate to US Dollar are affected in both the short-run and the long-run. We observed that if the COVID-19 cases are not managed properly by the government and the ministry of health, the impact by the health and economic crises would be worse and cause a more severe 


\section{(수)}

economic downturn. The health management and stimulus package were introduced by Malaysia, hoping that it will be the best solution to improve the economy of the country during this pandemic.

Acknowledgements. This research received no specific grant from any funding agency in the public, commercial, or not-for-profit sectors.

\section{References}

1 Baek, S., Mohanty, S. K., \& Glambosky, M. (2020). COVID-19 and stock market volatility: An industry level analysis. Finance Research Letters, 37(101748), 101748.

2 Arlinwibowo, J., Retnawati, H., \& Kartowagiran, B. (2021). How to Integrate STEM Education in Indonesian Curriculum? A Systematic Review. Challenges of Science. Issue IV, 2021, pp. 18-25. https://doi.org/10.31643/2021.03

3 Pratama H., Azman M. N. A., Zakaria N. A., Khairudin M. The effectiveness of the kit portable PLC on electrical motors course among vocational school students in Aceh, Indonesia. Kompleksnoe Ispol'zovanie Mineral'nogo Syr'a $=$ Complex Use of Mineral Resources. 2022. No 1 (320), pp. 75-86. https://doi.org/10.31643/2022/6445.09

4 Kassymova, G.K.; Vafazov, F.R.; Pertiwi, F.D.; Akhmetova, A.I.; Begimbetova, G.A. (2021). Upgrading Quality of Learning with E-Learning System. Challenges of Science. Issue IV, 2021, pp. 26-34. https://doi.org/10.31643/2021.04

5 Sha, Y., Sharma, S.S., 2020. Research on pandemics special issue of the journal emerging markets finance and trade. Emerg. Mark. Finance Trade 56, 2133-2137. http://dx.doi.org/10.1080/1540496X.2020.1795467.

6 Wang, Y.-H., Yang, F.-J., \& Chen, L.-J. (2013). An investor's perspective on infectious diseases and their influence on market behavior. Journal of Business Economics and Management, 14(1), S112-S127. https://doi.org/10.3846/16111699.2012.711360

7 Onali, E., 2020. COVID-19 and stock market volatility. SSRN: https://ssrn.com/abstract=3571453 or 10.2139/ssrn.3571453.

8 Carpentier, C., \& Suret, J.-M. (2015). Stock market and deterrence effect: A mid-run analysis of major environmental and non-environmental accidents. Journal of Environmental Economics and Management, 71, 1-18.

9 Narayan, P. K., Devpura, N., \& Wang, H. (2020). Japanese currency and stock Market-What happened during the COVID-19 pandemic? Economic Analysis and Policy, 68, 191-198.

10 Narayan, P. K. (2020). Has COVID-19 changed exchange rate resistance to shocks? Asian Economics Letters. https://doi.org/10.46557/001c.17389

11 Bertsatos, G., Sakellaris, P., \& Tsionas, M. G. (2021). Extensions of the Pesaran, Shin and Smith (2001) bounds testing procedure. Empirical Economics. https://doi.org/10.1007/s00181-021-02041-3

12 Pesaran, M. H., Y. Shin, and R. Smith, 2001, Bounds testing approaches to the analysis of level relationships. Journal of Applied Econometrics, 16, pp. 289-326.

13 Chandio, A. A., Jiang, Y., \& Rehman, A. (2019). Using the ARDL-ECM approach to investigate the nexus between support price and wheat production. Journal of Asian Business and Economic Studies, 26(1), 139-152. https://doi.org/10.1108/jabes-10-2018-0084 


\title{
КОВИД-19 ЖАҒДАЙЛАРЫНА КОР НАРЫҒЫНЫН РЕАКЦИЯСЫ: МА- ЛАЙЗИЯНЫН БОЛАШАҒЫ
}

\author{
Шайрил Изван T. ${ }^{1 *}$, Нилсон T. ${ }^{1}$, Эдвин $\Phi^{2}$, Бун Йик В. ${ }^{3}$, Г. К. Касымова \\ ${ }^{1}$ Әлеуметтік вылымдар және менеджмент бөлімі, гуманитарлық вылылмдар, \\ менеджмент және выльым факультеті, Малайзия университеті Путра, Малайзия \\ ${ }^{2}$ Бизнес және менеджмент кластері, Малайзияльқ ашық университет, Малай- \\ зия \\ ${ }^{3}$ Бизнес, экономика және есеп факультеті, Universiti Malaysia Сабах, Малайзия \\ ${ }^{4}$ Сәтбаев университеті, Металлургия және кен байыту институты; Абай \\ атындавы Қазақ ұлттық педагогикалық университеті, Алматы, Қазақстан \\ e-mail: shairil@upm.edu.my
}

Түйін. COVID-19 пандемиясы жаһандық ауқымда денсаулық пен экономикальққ давдарысқа әкелді. Бұл давдарыс толқындары Малайзияны 2020 жылдың наурыз айының басынан бастап қ̧амтыды. Бұл күтпеген давдарыс Малайзияның 2020 жылвы даму миссиясының алдында тұрван кедергілердің бірі больп табылады. Дегенмен, ел әлі де жоспарлау сызывында және өзінің миссиясы мен пайымдауын бөлісті. 2030 жыль өркендеу плины жоспарланган. Керісінше, бұл давдарыс кезінде әсіресе осал топтарва әсер ету құиын болды. Малайзияның қор нарыгы да зардап шекті. Үкімет экономиканы қалпына келтіру үшін ынталандыру пакетін енгізді. Бұл зерттеу 2020 жыл ішінде күндізгі саудава және макроэкономикальқ айнымалыларва хабарланван COVID-19 жавдайларының, әсеріне KLCI құатысты индексіне бавытталван. Біз коинтеграчияны анықтау және ARDL орындау үшін Bound Test қьолданамыз. Нәтижелер хабарланван жавдайлардың қысқа мерзімді және ұзақ мерзімді перспективада макроэкономикальқ айнымалыларва және қор нарывына айтарлықтай әсер ететінін көрсетеді. Қорытындылай келе, біз денсаулық давдарысын тиімді басқару экономикалық көрсеткіштерге теріс әсер етуді азайту және кез келген давдарыстан шыгу үшін ең жақусы шешімдердің бірі екенін анықтадық.

Түйін сөздер: COVID-19, Стата, Өсу, Қор нарывы.

\section{РЕАКЦИЯ ФОНДОВОГО РЫНКА НА СЛУЧАИ СОVID-19: ОТКРЫВАЯ БУДУЩЕЕ МАЛАЙЗИИ}

Шайрил Изван Т. ${ }^{1 *}$, Нилсон Т. ${ }^{1}$, Эдвин $\Phi^{2}$, Бун Йик В. ${ }^{3}$, Г. К. Касымова

${ }^{1}$ Кафедра соичальных наук и менеджмента, факультет гуманитарных наук, менеджмента и естественных наук, Universiti Putra Malaysia, Campus Bintulu, Maлайзия.

${ }^{2}$ Кластер бизнеса и менеджмента, Открытый университет Малайзии, Малайзия

${ }^{3}$ Факультет бизнеса, экономики и бухгалтерского учета, Университет Малайзии, Сабах, Малайзия

${ }^{4}$ Институт металлургии и обогащения, Satbayev University; Казахский национальный педагогический университет им. Абая, Алматы, Казахстан e-mail: shairil@,upm.edu.my 
Резюме. Пандемия COVID-19 вызвала серьезный кризис в области здравоохранения и экономики в глобальном масштабе. Волны этого кризиса обрушились на Малайзию с начала марта 2020 года. Этот непредвиденный кризис является одним из препятствий, с которыми Малайзия сталкивается на пути к миссии развития странь в 2020 году. Однако страна все еще находится в стадии планирования и представила свою миссию и видение общего процветание к 2030 году. Напротив, во время этого кризиса особенно сильно пострадали уязвимые группы. Пострадал и фондовый рынок Малайзии. Правительство представило пакет стимулов, чтобы попытаться восстановить экономику. В этом исследовании основное внимание уделяется индексу KLCI, отражающему влияние зарегистрированных случаев COVID-19 на дневную торговлю и макроэкономические переменные в течение 2020 года. Мы используем Bound Test для выявления совместной интеграчии и выполнения ARDL. Результаты показывают, что описанные случаи оказывают значительное влияние на макроэкономические переменные и фондовый рынок как в краткосрочной, так и в долгосрочной перспективе. $B$ заключение мы пришли к выводу, что эффективное управление кризисом в области здравоохранения является одним из лучших решений для снижения негативного воздействия на экономические показатели и выхода из любого кризиса.

Ключевые слова: Covid-19, Stata, рост, фондовый рынок. 